\title{
A TWO FAMILY HOUSE BUILT TO PASSIVE HOUSE STANDARD IN THE NORTH OF SWEDEN - ENVIRONMENTAL SYSTEM PERFORMANCE
}

\author{
Jonas Jonasson* \\ Itai Danielski \\ Michelle Svensson \\ Morgan Fröling \\ Department of Echotechnology and Sustainable Building Engineering, \\ Mid Sweden University, Östersund, Sweden \\ *Corresponding author: jonas.jonasson@miun.se
}

\begin{abstract}
A life cycle assessment (LCA) of a low energy / passive house in northern Sweden, including building materials and energy use is reported. The case study building is semi detached house for two families situated in Östersund (lat. $63^{\circ} \mathrm{N}$ ), Sweden. Each apartment having a floor space of $160 \mathrm{~m}^{2}$ divided on two floors. The building was constructed during 2010 with a design meeting the requirements for Swedish passive houses as defined by the Forum for energy efficiency buildings (FEBY) and the Swedish center for zero energy houses (SCNH). When it comes to more sustainable buildings, energy use in the build environment has been in focus for some time. The life cycle assessment in this study reveals that the building materials can contribute significantly to environmental burdens of a residential building in northern Sweden. Energy efficiency, efficient use of good building materials and issues of appropriate design need to be discussed in the same context to move toward a more sustainable built environment.

For energy efficient buildings in a energy system with renewably based energy carriers, building materials might give rise to a significant or even dominating part of the life cycle impact of a building. This give rise to considerations regarding choices of building materials as well as design of buildings to minimize such impact; while not forgetting social aspects impacted by building design. https://doi.org/10.15626/Eco-Tech.2014.003
\end{abstract}

\section{KEYWORDS}

Passive house, LCA, Energy assessment, Building material

\section{INTRODUCTION}

The International Passive House Association [1] describes a passive house as having:

- exceptionally high level of thermal insulation,

- well-insulated window frames with triple low-e glazing,

- thermal-bridge-free construction, 
- $\quad$ airtight building envelope,

- and comfort ventilation with highly efficient heat recovery.

The certification requirements for passive houses in the international standard, which is developed by the Passive House Institute includes: the space heating demand must not be more than $15 \mathrm{kWh}$ per square meter of usable living space per year. Alternatively, the heating load must not exceed $10 \mathrm{~W} / \mathrm{m} 2$. If active cooling is required to ensure comfort in summer, the energy demand for this is also limited to $15 \mathrm{kWh} /(\mathrm{m} 2 y e a r)$. The specific primary energy demand for the total amount of domestic hot water, heating, cooling, auxiliary electricity, domestic and common area electricity must not exceed $120 \mathrm{kWh} /(\mathrm{m} 2 \mathrm{year})$ [2].

The criteria for passive houses differ among different countries depending on existing local climates and building codes. For example, the Swedish centre for zero energy houses (SCNH), define passive houses as: "houses that has a high level of comfort, good quality, uses minimal energy and contributes to the reduction of carbon emissions" [3]. SCNH is a non-profit organization with the aim to promote the construction of low energy buildings, including passive houses. SCNH has released the Swedish passive house definition FEBY 12 [4], which lists the criteria for zero energy-, passive- and mini energy- houses. The criteria take into account the international criteria but with adjustments to three different Swedish northern climate zones defined by the Swedish National Board of Housing, Building and Planning, as listed in Table 1. There are two main criteria: (i) the ratio of heat load demand to the heated floor area of the building; and (ii) the specific final energy demand. The two criteria are listed in Table 1 for the different climate zones.

The case study analyzed is a low energy house built in Östersund (lat $63^{\circ} \mathrm{N}$ ), Sweden. The building is a semi detached house for two families, with each apartment having a floor space of $160 \mathrm{~m} 2$ divided on two floors. Each housing part comprises one garage, one storage/garbage room, one laundry room, one hall, one cloakroom, one living room, one kitchen, four bedrooms, one WC/shower, one WC/bath, one balcony, one terrace of wooden decking, two walk-in closets and one inside storeroom (thus the double for the entire house). The house has a wooden frame, an exterior of wood paneling, insulation of cellulose fiber, stone wool and glass wool, a concrete slab with steel mesh on foam sheets (cellular plastics) and macadam, and a roof made of sheet metal. The windows, the doors and the interior stairs are made of wood, glass and metal. The building was constructed during 2010 according to the Swedish passive house principles, with design that meet the requirements for Swedish passive houses defined by the Forum for energy efficiency buildings (FEBY) and the Center for zero energy buildings (SCNH).

The two identical residential units in the building were inhabited in the end of 2010 by two families with different characteristics; one family with two young children in one unit and a middle-aged couple in the other.

A one year energy measurement campaign started in May 2012 for both of the residential units.

Table 1. Swedish passive house criteria

\begin{tabular}{lllll}
\hline Climate zone: & & $\mathrm{I}$ & $\mathrm{II}$ & $\mathrm{III}$ \\
\hline Heat load demand & $\mathrm{W} / \mathrm{m}^{2}$ & 19 & 18 & 17 \\
For non-electric heating systems & $\mathrm{kWh} /\left(\mathrm{m}^{2}\right.$ year $)$ & 63 & 59 & 55 \\
For electric heating systems & $\mathrm{kWh} /\left(\mathrm{m}^{2}\right.$ year $)$ & 31 & 29 & 27 \\
For combination of different type of energy systems & $\mathrm{kWh} /\left(\mathrm{m}^{2}\right.$ year $)$ & 78 & 73 & 68 \\
\hline
\end{tabular}


The measurements are performed by Närhus, together with the Department of Ecotechnology and Sustainable Building at Mid Sweden University in Östersund, Jämtkraft, Marklunds El, YIT and WSP. The measurements started after a period of adjustments of the buildings energy system and include: space and domestic water heating (separate measurements), household electricity, the amount of fuel wood used in the stove, the efficiency of the ventilation heat recovery and indoor thermal conditions. Based on the measurements the energy performance of a passive house building in the climate of northern Sweden has been evaluated [5].

This study investigates specifically the construction of the passive house Röda Lyktan in Östersund, Sweden, erected in year 2010, and the measured final energy use during one year of use of the building 2012-2013. The choice of what materials to include is based on high volumes in the building and if they were specifically important for achiving passive house standard. Note that the demolition phase is not included.

\section{METHOD}

The goal of this LCA is to investigate the environmental impact of the building materials and

Table 2. What is included and excluded in the study

\begin{tabular}{|l|l|}
\hline Included & Excluded \\
\hline Framework & Transports from factories for building materials \\
\hline Foundation & Construction energy \\
\hline Outer and inner walls & Waste in the construction \\
\hline Ceiling/roof & Garage and garbage room \\
\hline Middle floor structure & Terrace \\
\hline Floor coverings & Balcony \\
\hline Doors & Garden \\
\hline Windows & Fences \\
\hline Interior staircase and banister & Downpipes and rain gutters \\
\hline FTX-ventilation & Snow railings \\
\hline Wood stove & District heating central with heat exchanger \\
\hline Energy used in the use phase calculated & \\
\hline on a 50 years period. & Appliances \\
\hline & Permanent fixtures like closets, shelves and \\
\hline & drawers \\
\hline & Electrical installations \\
\hline & Underfloor heating pipes \\
\hline & Other plumbing material such as drainage pipes, \\
\hline & sewers, water pipes etc \\
\hline & Toilets, bathtubs, showers, wash basins, sinks etc \\
\hline & Paint and wallpaper \\
\hline & Sealing strips for the windows \\
\hline & Argon gas between the glasses in the windows \\
\hline & Fittings for windows and doors \\
\hline & Locks, keys and handles for the doors \\
\hline & Rails, screws and escutcheons \\
\hline & Demovations \\
\hline & \\
\hline &
\end{tabular}

how they compare to the impact of the energy use in the use phase of the building. 
The investigation will be a case study of the passive house Röda Lyktan, Östersund, Sweden. This LCA also aim to identify which materials in the construction of the passive house that has the highest environmental impact in global warming potentials, cumulative energy demand, ecotoxicity and human toxicity.

The foreground inventory of the materials in the house has been carried out mainly by studying blueprints on the house, but some additional data has been collected through interviews with Magnus Rindberg that was the developer of the house. The inventory of the energy use during the use phase was based on[5].

For background data describing upstream activities, the LCI database Ecoinvent [6]was used. It is a database with consistently modeled and transparently reported, LCI datasets.

\section{RESULTS AND DISCUSSION}

An overview of the impact assessment results can be found in the graphs in Figure 1, 2, and 3. The FTX-ventilation is illustrated with a dotted line that represents the whole value, whereas the colored area in the staple represents 2/6 of the value, because the value accessible in Ecoinvent was for a larger ventilation system dimensioned for 6 apartments. The Röda Lyktan building only has 2 apartments, and therefore the environmental impact is reduced to 2/6 of the full value. The Metals and Insulation materials bars are shown with subcategories to illustrate which specific material that gives the contribution.

Figure 1 shows that the insulation materials give the highest GWP value of the construction phase.

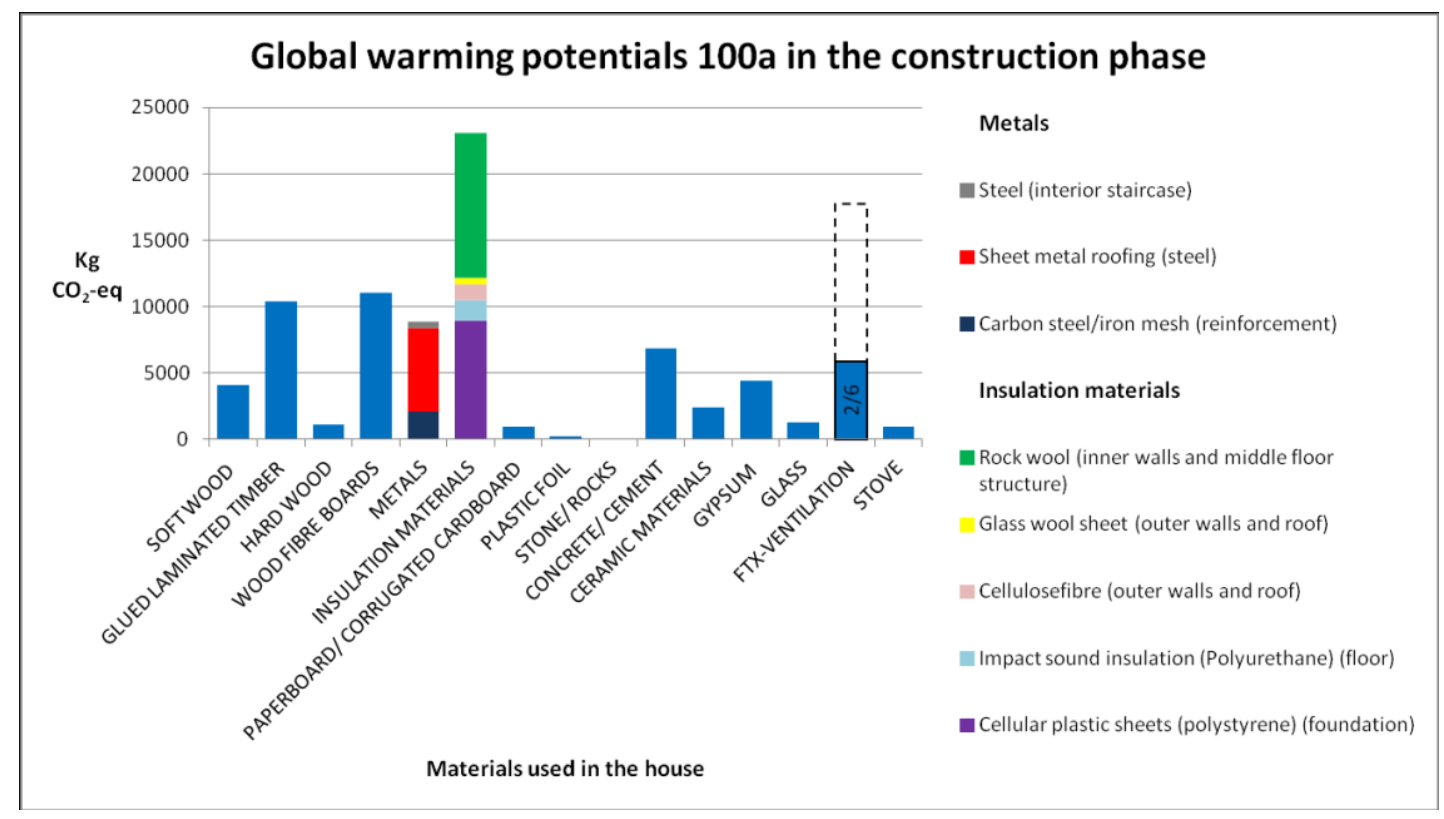

Figure 1 Global Warming Potentials, Construction phase 


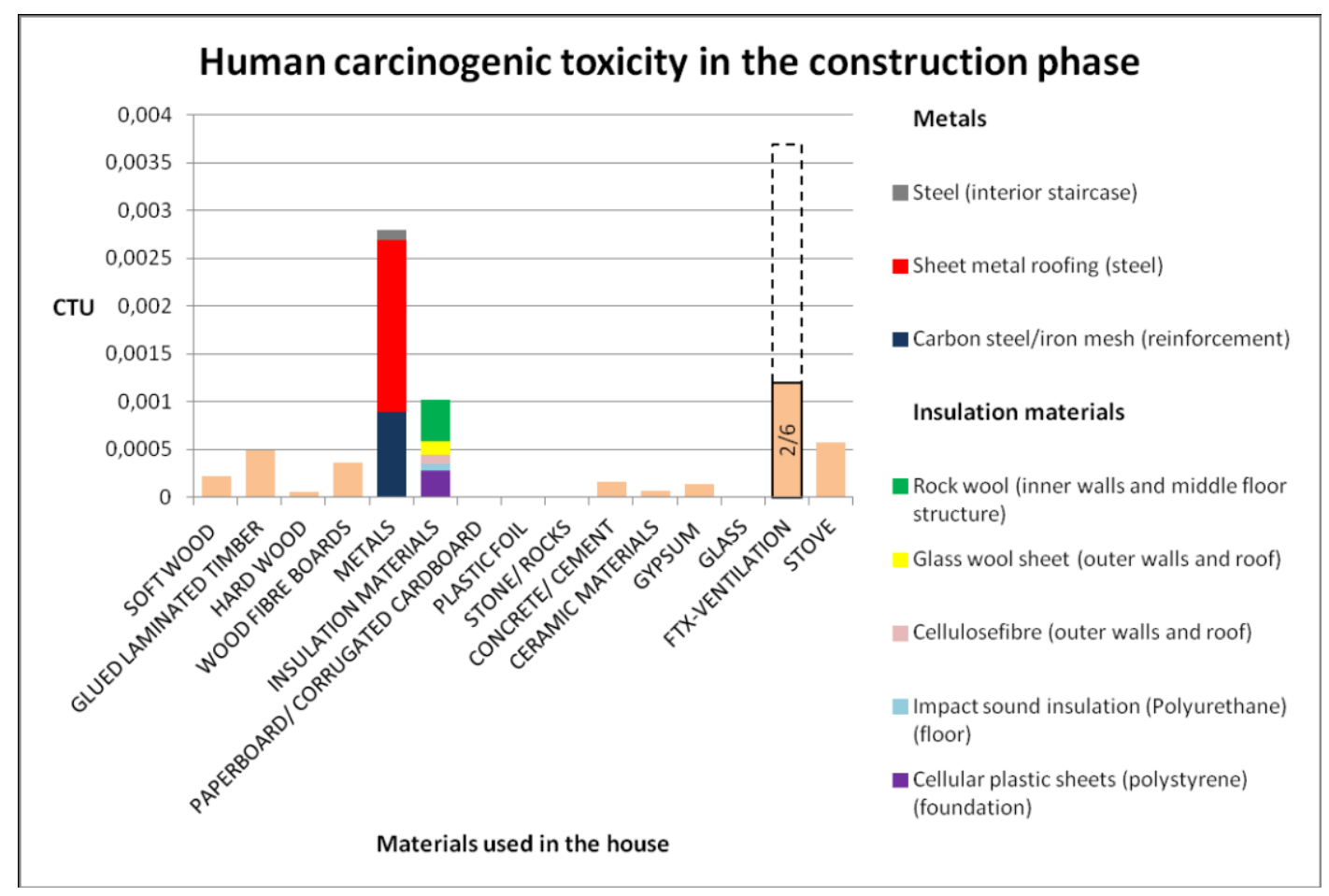

Figure 2 Human carcinogenic toxicity

Of the insulation materials the rock wool and the cellular plastic sheets has the highest values.

Wood fibre boards have the second highest value and glued laminated timber the third highest. Then comes the metals with sheet metal roofing as the highest values.

The value for the whole ventilation is on the second highest staple, but for the 2/6 value it ends up on sixth place from the top right after concrete/cement.

Figure 2 shows the values for the human carcinogenic toxicity in the construction phase. The whole ventilation has the highest values but the $2 / 6$ of the ventilation ends up on second place. Metals (with sheet metal roofing as highest value), has the highest values (aside from the whole ventilation value), insulation materials (with rock wool and cellular plastic sheets as highest value) comes on third place and the stove and glued laminated timber on fourth and fifth place.

The comparison in figure 4 shows that the use phase has $56 \%$ of the GWP compared to the construction phase which has $44 \%$. The use phase has $81 \%$ of the total primary energy while the construction phase has $19 \%$. Regarding the ecotoxicity the use phase has $61 \%$ and the construction phase $39 \%$. Regarding the human carcinogenic toxicity the use phase has $46 \%$ while the construction phase has $54 \%$. Regarding the human non-carcinogenic toxicity the use phase has $82 \%$ while the construction phase has $18 \%$. The total human toxicity has almost the same numbers as the non-carcinogenic toxicity, $80 \%$ for the use phase and $20 \%$ for the construction phase 


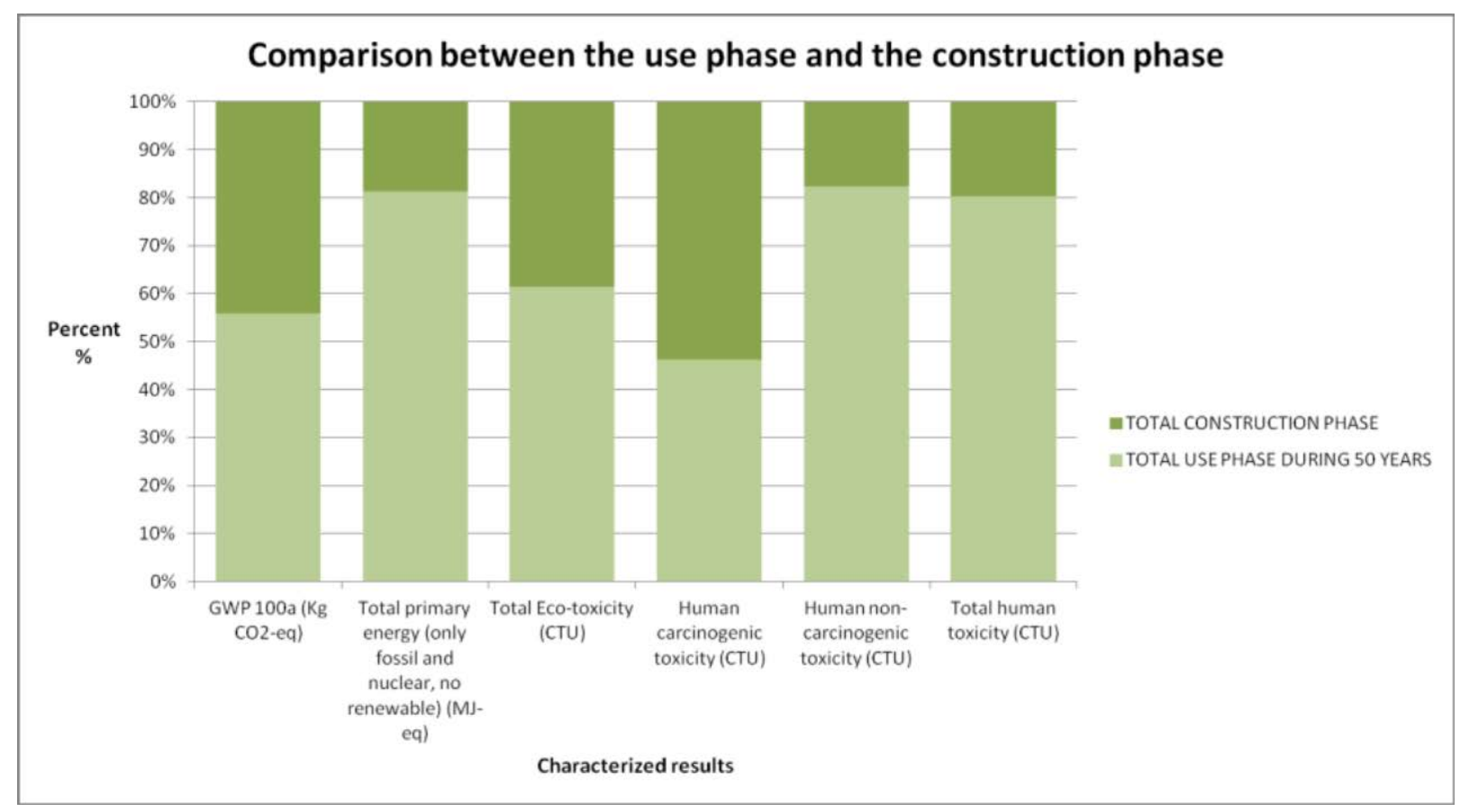

Figure 3 Comparison between the use phase and the construction phase

\section{CONCLUSIONS}

For energy efficient buildings in a energy system with renewably based energy carriers, building materials might give rise to a significant or even dominating part of the life cycle impact of a building. Using a low GWP energy source for heating makes the LCA GWP of the building materials a significant part of the buildings total GWP. The construction of the FTX-ventilation also induces a unexpectedly high environmental impact. This give rise to considerations regarding choices of building materials as well as design of buildings to minimize such impact.

\section{ACKNOWLEDGMENTS}

We gratefully acknowledge the financial support of the European Union Regional Development Fund

\section{REFERENCES}

[1] International Passive House Association (IPHA), 2014. Active for more comfort: Passive House. Information for property developers, contractors and clients, Available at: http://www.passivehouse-international.org/upload/ipha-brochure/.accessed 15 October, 2014.

[2] Passive House Institute, 2013. Certified Passive House, Certification criteria for residential Passive House buildings,

Available at: http://www.passiv.de/downloads/03_certification_criteria_residential_en.pdf , accessed 15 October, 2014.

[3] Swedish centre for zero energy houses (SCNH), 2013. Om FEBY 12 (About FEBY 12). Available at: http://www.nollhus.se/feby-12/om-feby-12 , accessed 15 October, 2014 
[4] Swedish centre for zero energy houses (SCNH), 2013. Kravspecifikation för nollenergihus, passivhus och minienergihus Bostäder (The specification for zero energy, passive and minienergyhouses Buildings). Available at:

http://www.nollhus.se/dokument/Kravspecifikation\%20FEBY12\%20-

\%20bostader\%20sept.pdf , Accessed 15 October, 2014.

[5] Danielski, I., Svensson, M., Fröling, M., 2013. Adaption of the passive house concept in northern Sweden - a case study of performance. Passivhus Norden 2013, Göteborg, SwedenMid Sweden University, Östersund, Sweden, 15-17 October, 2013.

[6] Ecoinvent. (2013) Available at: http://www.ecoinvent.org/ Accessed during April and May 2013. 